\title{
COVID-19 Pandemisi Döneminde İntörn Hemşirelerin Mesleki İmaj Algılarının İncelenmesi*
}

\author{
Ayşe DOST ${ }^{* *}$, Derya ASLAN HUYAR ${ }^{* * * *}$, Hatice Büşra TUNÇAY****
}

\section{Öz}

Amaç: Bu çalışma COVID-19 pandemisi döneminde intörn hemşirelerin mesleki imaj algılarının incelenmesi amacıyla yapıldı.

Yöntem: Tanımlayıcı tipte olan araştırmanın örneklemini 2020-2021 akademik eğitim öğretim yılında bir vakıf üniversitesinin hemşirelik bölümü 4.sınıf programında kayıtlı olan 170 intörn hemşire oluşturdu. Veriler "Kişisel Bilgiler Formu” ve "Hemşirelik Mesleğine Yönelik İmaj Ölçeği (HMYIÖ)” kullanılarak Google Forms ile toplandı.

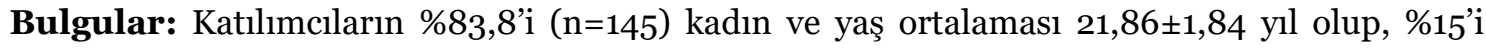
(n=26) COVID-19 tanısı aldığını belirtmiştir. \%89,6'sının hemşirelik mesleğini isteyerek seçtiği, \%59,5’inin salgında aktif olarak çalışmak istediği, salgın sürecinde endişe boyutlarına dair \%67,1'inin "kaygı duyuyorum" yanıtını verdiği, en çok korku, endişe hissettikleri ve bu durumun geçici olduğunu belirttikleri saptandı. İntörn hemşirelerin mesleki imaj ölçeği puanı 153,76 $\pm 9,38$ (min.-max.değerler: 102-174) puan olarak tespit edilmiştir. Kaygı duyduğunu belirten, hemşireler

\section{Özgün Araştırma Makalesi (Original Research Article)}

Geliş / Received: 17.05.2021 \& Kabul / Accepted: 02.06.2021

DOI: https://doi.org/10.38079/igusabder.937846

* Bu araştırma 2.Uluslararası 3.Ulusal Halk Sağlığı Hemşireliği Kongresi’nde sözel bildiri olarak sunulmuştur.

${ }_{* * *}^{*}$ Dr. Öğr. Üyesi, İstanbul Medipol Üniversitesi, Sağlık Bilimleri Fakültesi, Hemşirelik Bölümü, İstanbul, Türkiye, E-posta: adost@medipol.edu.tr ORCID https://orcid.org/o000-0002-46517254

${ }_{* * *}$ Öğr. Gör. Dr., Bursa Uludağ Üniversitesi, Sağllk Hizmetleri Meslek Yüksekokulu, İlk ve Acil Yardım Programı, Bursa, Türkiye, E-posta: deryaslan@uludag.edu.tr

ORCID https://orcid.org/o000-0003-2916-7907

***** Hemşire, İstanbul Medipol Üniversitesi, Sağlık Bilimleri Yüksekokulu, Hemşirelik Bölümü, İstanbul, Türkiye, E-posta: haticebusratuncay@gmail.com ORCID https://orcid.org/oooo0002-9750-8403

ETİK BİLDÍRIM: Araştırma öncesi kurumdan ve İstanbul Medipol Üniversitesi Etik Kurulu Başkanlığından (10840098-772.02-E.61567) onay alınmıştır. Sağlık Bakanlığı’ndan çalışma izni alınmıştır. Araştırmaya katılan intörn hemşirelik öğrencilerinden Google Forms uygulaması aracılı̆̆ıyla bilgilendirilmiş onam formu alınmıştır. 
için alınan önlemleri yeterli bulmayan ve hemşirelik mesleğini isteyerek seçmeyen intörn hemşirelerin HMYİÖ sıra ortalamalarının mesleği isteyerek seçenlere göre düşük olduğu saptandı $(\mathrm{p}<0,05)$.

Sonuç: COVID-19 pandemisi sürecinde intörn hemşirelerin mesleki imaj algılarının iyi düzeyde olduğu, ancak kaygı ve korku düzeylerinin yüksek ve çalışma koşulları alt ölçeği puanlarının düşük olduğu belirlendi.

Anahtar Kelimeler: Hemşirelik, imaj, pandemi.

\title{
Examination of Intern Nurses' Perceptions of Professional Image During the COVID-19 Pandemic Period
}

\begin{abstract}
Aim: This study was conducted to examine the professional image perceptions of nurse interns during the COVID-19 pandemic.

Method: The sample of the descriptive study consisted of 170 nurse interns enrolled in the 4th year program of the nursing department of a foundation university in the academic year of 20202021. The data were collected with google forms using the Personal Information Form and the "Image Scale for Nursing Profession".

Results: $83,8 \%(n=145)$ of the participants were women and the average age was $21,86 \pm 1,84$ years, and $15 \%(n=26)$ stated that they were diagnosed with COVID-19. It was determined that $89.6 \%$ chose the nursing profession willingly, 59,5\% wanted to work actively in the pandemic, $67,1 \%$ answered "I am anxious" about the dimensions of anxiety during the pandemic process, felt the most fear and anxiety and stated that this situation was temporary. The professional image scale score of the intern nurses was determined as 153,76 \pm 9,38 (min-max values: 102-174) points. It was determined that the mean rank of interns who stated that they were anxious, did not find the measures taken for the nurses sufficient, and did not choose the nursing profession willingly, was statistically significantly lower than those who chose the profession voluntarily ( $p$ $<0,05)$.
\end{abstract}

Conclusion: During the COVID-19 pandemic, it was determined that intern nurses had a good professional image perception, but their anxiety and fear levels were high and their working conditions subscale scores were low.

Keywords: Nursing, image, pandemic. 


\section{Giriș}

COVID-19, Çin Halk Cumhuriyeti’nin Wuhan kentinde 2019 yılının Aralık ayında ilk olarak görülmüştür. Belirtileri arasında ateş, kuru öksürük, yorgunluk, solunum güçlüğü ve göğüs ağrısı yer alırken damlacık yoluyla bulaştığı tanımlanmıştır ${ }^{1}$. Bu virüs kısa sürede dünyada geniş alanlara yayllarak halk sağlı̆̆ sorunu olmuştur. 11 Mart 2020 tarihinde Dünya Sağlık Örgütü (DSÖ) pandemi ilan etmiştir² 16 Mayıs 2021 tarihindeki güncel verilere göre Türkiye'deki toplam vaka sayısı 5.106.862, toplam vefat sayısı 44.537, toplam iyileşen sayısı ise $4.932 .838{ }^{\prime}$ dir $^{3}$.

Pandemi ilan edildiği günden bu yana hızla artan vaka sayılarıyla birlikte hemşirelerin yükü de artmıştır. Hemşireler sağlık sektörünün bel kemiği olup, bir ülkenin tüm vatandaşlarına kaliteli bakım sağlanmasında temeli oluşturmaktadırlar. İnsan hayatı ve sağlı̆̆ söz konusu olduğunda hemşireler, içinde bulunduğumuz salgında da ön kısımda yer almaktadır. COVID-19 tedavisi ve bakımına kısa sürede uyum sağlayan hemşireler hastalara fiziksel ve psikolojik bakım vermektedir ${ }^{1}$. Dolan yoğun bakım ve hastane kapasiteleri uzun ve yoğun çalışma saatlerini de beraberinde getirmiştir. Bununla birlikte hemşirelerin COVID-19 virüsüyle enfekte olma riski artmaktadır. Hemşireler fiziksel olarak tüketen yoğun tempolu çalışma saatlerine ek olarak virüsü ailesine bulaştırma korkusuyla psikolojik sorunlar yaşamaktadır ${ }^{4}$. Bunlara rağmen hemşireler mesleklerini halkı sağlığına kavuşturmak adına büyük bir özveriyle sürdürmektedir.

Pandemi COVID-19'un neden sıkıntıları gündemde tutarken, günümüz hemşirelik işgücünün olumsuz çalışma koşullarını ve karşılaştıkları zorlukları da net bir şekilde gözler önüne serilmiştir. COVID-19'un yarattı̆̆ı yoğun zorluklara ön safhada yanıt vermeye çalışan hemşirelere duyulan takdir, şükran ve hatta sevgi sosyal medya aracılığı ile kamuoyunda yayılmıştır. Sağlık sorunlarını ele almak, halk sağlığını geliştirmek ve insanların hayatlarını doğrudan kurtarmak için çalışan bir meslek olarak hemşirelerin statü ve gücü vurgulanmıştır5.

Hemşirelerin mesleğine karşı algı, görüş ve tutumlarının birleşmesiyle oluşan mesleki imaj algısı, meslekteki iş doyumunu, performansı ve meslekte kalmayı etkilemektedir6 ${ }^{6}$ Hemşirelerin pandemi sürecine yakından tanık olmasından dolayı psikolojilerinin olumsuz etkilendiği yapılan çalışmalarla ortaya konulmuştur7-11. Özellikle COVID-19 pandemisinde artan iş yükü ve çalışma saatleri sebebiyle hemşireler tükenmişlik, 
yorgunluk ve ailesine virüsü taşıma korkusuyla endişe yaşadıkları saptanmıştır ${ }^{1}$ İntörn hemşirelik öğrencilerinin pandemi döneminde mesleki imaj algılarının olumsuz yönde etkilenmesi, meslekten uzaklaşmalara ve bakım kalitesinde azalma gibi sonuçlara neden olabileceği düşünülmektedir. Bu araştırma COVID-19 pandemisi döneminde intörn hemşirelik öğrencilerinin mesleki imaj algılarının belirlenmesi amacıyla yapılmıştır.

\section{Araştırma Soruları}

- İntörn hemşirelik öğrencilerinin mesleki imaj algıları ne düzeydedir?

- İntörn hemşirelik öğrencilerinin kişisel özellikleri ile Hemşirelik Mesleğine Yönelik İmaj Ölçeği toplam puanı ve alt boyutları puan ortalamaları arasında anlamlı fark var mıdır?

\section{Gereç ve Yöntem}

Araştırma Tipi: Araştırma tanımlayıcı tiptedir.

Araştırmanın Evreni ve Örneklemi: Araştırmanın evrenini, 2020-2021 akademik eğitim öğretim yılında bir vakıf üniversitesinin hemşirelik bölümü 4.sınıf programında kayıtlı olan 213 intörn hemşire oluşturdu. Araştırmada evrenin tamamına ulaşılması amaçlanmış olup, araştırmaya gönüllü olarak çalışmaya katılmayı kabul eden 170 intörn hemşire (Evrenin karşılanma oranı: \% 79) örneklem grubunu oluşturdu. Veriler Google Forms uygulaması ile toplandı. Veri toplama araçlarının doldurulma süresi 15-20 dakikadır.

Veri Toplama Araçları: Veri toplama aracı "Kişisel Bilgi Formu" ve "Hemşirelik Mesleğine Yönelik İmaj Ölçeği” olmak üzere iki bölümden oluşmaktadır.

Kişisel Bilgi Formu: Araştırmacılar tarafından geliştirilen öğrencilerin demografik özelliklerinin ve COVID-19 pandemisinde mesleki tutumlarının belirlenmesine yönelik 11 sorudan oluşan bir formdur.

“Hemşirelik Mesleğine Yönelik İmaj Ölçeği”: Hemşirelerin mesleki imaj algılarını belirlemek amacıyla "Dost ve Bahçecik" tarafından 2015 yılında geliştirilen 5 li likert tipindeki ölçek, 6 faktör ve 42 maddeden oluşmaktadır. Ters çevrilerek kodlanması gereken maddeler ise 8, 14, 15, 17, 18, 20, 21, 22, 23, 24, 25, 26, 28, 29 ve 31. maddelerdir. Ölçekten alınabilecek puan 42 ile 210 puan arasında değişmekte olup, ölçek toplam puanı arttıkça, imaj algısı da olumlu yönde artmaktadır. Ölçeğin Cronbach Alfa katsayısı 
$\alpha=0,82$ olarak bulunmuş olup, bu araştırmada $\alpha=0,88$ olarak bulundu. Buna göre ölçüm sonuçlarının yüksek derecede güvenilir olduğu belirlenmiştir ${ }^{12}$.

Etik Konular: Araştırma öncesi kurumdan ve İstanbul Medipol Üniversitesi Etik Kurulu Başkanlığından (10840098-772.02-E.61567) onay alınmıştır. Sağlık Bakanlığı'ndan çalışma izni alınmıştır. Araştırmaya katılan intörn hemşirelik öğrencilerinden Google Forms uygulaması aracılığıyla bilgilendirilmiş onam formu alınmıştır.

Verilerin Analizi: Araştırmada verileri SPSS 22.0 programı kullanılarak değerlendirilmiş olup, Shapiro-Wilk testi sonucu p>0,05 olarak bulunduğundan verilerin normal dağılmamakta olduğu görüldü ve non parametrik testler kullanıldı. Anlamlılık düzeyi $\mathrm{p}<0.05$ olarak kabul edildi. Tanımlayıcı istatistiksel analiz yöntemlerinden sayı, yüzde, ortalama ve standart sapma kullanıldı. Ölçekler ve alt boyutlarının toplam puan ortalamalarının sosyodemografik özellikler ile karşılaştırılmasında non parametrik Mann Whitney U, Kruskal Wallis testi kullanıldı.

\section{Bulgular}

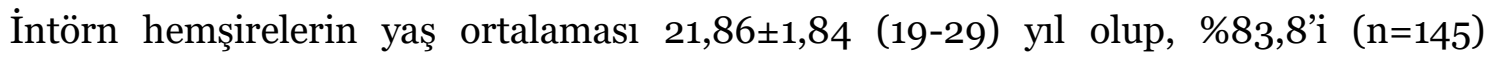
kadındır. Öğrencilerin \%15’i (n=26) COVID-19 tanısı aldığını belirtmiştir. İntörn hemşirelerin \%89,6’sı hemşirelik mesleğini isteyerek seçtiğini, \%59,5’i salgında aktif olarak çalışmak istediğini belirtmiştir. Salgın sürecinde endişe boyutlarına dair \%67,1’i en çok "kaygı duyuyorum" yanıtını vermiş olup, en çok hangi duygu ve düşüncelere sahip oldukları sorgulandığında korku ve endişe hissettikleri tespit edilmiştir. İntörn hemşirelerin \%62,1’i hemşirelerin güvenliğine yönelik sağlık kurumlarında alınan önlemleri yeterli bulmadıklarını belirtmişlerdir (Tablo 1). 
Tablo 1. İntörn hemşirelik öğrencilerinin bireysel özelliklerinin dağılımı

\begin{tabular}{|c|c|c|c|c|}
\hline \multirow[b]{2}{*}{ Bireysel Özellikler } & \multirow[b]{2}{*}{ Sayı } & \multirow[b]{2}{*}{ Yüzde } & \multicolumn{2}{|c|}{ Hemşirelik Mesleğine Yönelik İmaj Ölçeği } \\
\hline & & & Sira ortalamasi & Test ve p değeri \\
\hline \multicolumn{5}{|l|}{ Cinsiyet } \\
\hline Kadin & 145 & 83,8 & 87,26 & \multirow{2}{*}{$\begin{array}{l}Z=-.155 \\
p=0.877\end{array}$} \\
\hline Erkek & 28 & 16,2 & 85,66 & \\
\hline \multicolumn{5}{|l|}{ COVID-19 tanısı alma durumu } \\
\hline Evet & 26 & 15,0 & 93,21 & \multirow{2}{*}{$\begin{array}{c}\mathrm{Z}=-0.687 \\
\mathrm{p}=0.492\end{array}$} \\
\hline Hayır & 147 & 85,0 & 85,90 & \\
\hline \multicolumn{5}{|c|}{ COVID-19 pandemisinde aktif olarak çalışmak isterim } \\
\hline Evet & 103 & 59,5 & 91,80 & \multirow{2}{*}{$\begin{aligned} Z & =-1,531 \\
p & =0,126\end{aligned}$} \\
\hline Hayır & 70 & 40,5 & 79,94 & \\
\hline \multicolumn{5}{|l|}{ COVID-19 pandemisinden } \\
\hline Çok kaygı duyuyorum (a) & 39 & 22,5 & 78,09 & \multirow{5}{*}{$\begin{array}{c}\mathrm{KW}=5,650 \\
\mathrm{p}=\mathrm{o}, 027 \\
\mathrm{~b}<\mathrm{a}<\mathrm{d}<\mathrm{c}<\mathrm{e}\end{array}$} \\
\hline Kaygı duyuyorum (b) & 116 & 67,1 & 68,33 & \\
\hline Her zamanki gibi hissediyorum (c) & 12 & 6,9 & 100,83 & \\
\hline Rahat hissediyorum (d) & 4 & 2,3 & 85,00 & \\
\hline Çok rahat hissediyorum (e) & 2 & 1,2 & 144,50 & \\
\hline \multicolumn{5}{|c|}{ Hemşireler için alınan önlemleri yeterli bulma durumu } \\
\hline Evet (a) & 3 & 1,7 & 117,00 & \multirow{3}{*}{$\begin{array}{c}\mathrm{KW}=18,217 \\
\mathrm{p}=0, \mathrm{ooO} \\
\mathrm{c}<\mathrm{a}, \mathrm{b}\end{array}$} \\
\hline Kismen (b) & 62 & 35,8 & 107,43 & \\
\hline Hayır (c) & 108 & 62,4 & 74,44 & \\
\hline \multicolumn{5}{|c|}{ Hemşirelik mesleğini isteyerek seçme durumu } \\
\hline Evet & 155 & 89,6 & 90,24 & \multirow{2}{*}{$\begin{aligned} Z & =-2,501 \\
p & =0,012\end{aligned}$} \\
\hline Hayır & 18 & 10,4 & 59,08 & \\
\hline
\end{tabular}


İntörn hemşirelerin HMYIÖ ve alt boyutlarından aldıkları puan ortalamaları

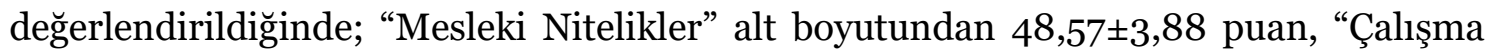
Koşulları” alt boyutundan 25,80 $\pm 2,49$, “Cinsiyet” alt boyutundan 27,79 $\pm 6,14$ puan,

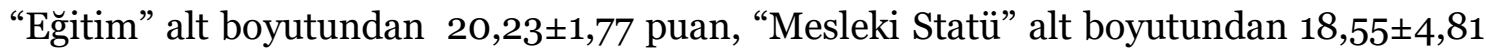

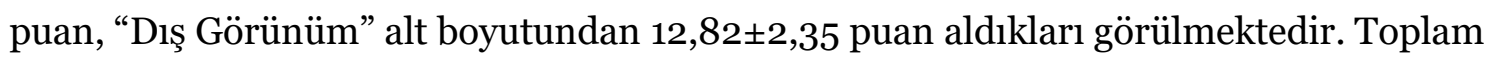
imaj ölçeği ortalama puanı; 153,76 $\pm 9,38$ 'dır. Ölçeği geliştiren araştırmacı tarafından alınan toplam puan için belirlenen skalaya göre 144-177 puan aralığı "iyi imaj algısı olarak” tanımlanmıştır (Tablo 2).

Tablo 2. "Hemşirelik Mesleğine Yönelik İmaj Ölçeği” ve alt boyutları puanları (n=170)

\begin{tabular}{|l|c|c|c|c|}
\hline Ölçek ve Alt Boyutları & Minimum & Maksimum & Ortalama & Standart Sapma \\
\hline Mesleki Nitelikler & 15,00 & 51,00 & 48,57 & 3,88 \\
\hline Çalışma Koşulları & 20,00 & 39,00 & 25,80 & 2,49 \\
\hline Cinsiyet & 12,00 & 36,00 & 27,79 & 6,14 \\
\hline Eğitim & 9,00 & 23,00 & 20,23 & 1,77 \\
\hline Mesleki Statü & 5,00 & 25,00 & 18,55 & 4,81 \\
\hline Dış Görünüm & 3,00 & 15,00 & 12,82 & 2,35 \\
\hline Toplam & 102,00 & 174,00 & 153,76 & 9,38 \\
\hline
\end{tabular}

İntörn hemşirelerin HMYIÖ ölçeği sıra ortalamaları ile bireysel özellikleri karşılaştırıldığında, pandemi yönelik endişe durumu, hemşireler için alınan önlemleri yeterli bulma durumu ve mesleği isteyerek seçme durumu ile HMYIÖ ölçeği sıra ortalamaları arasında anlamlı farklılık olduğu tespit edildi ( $<<0,05)$. Kaygı duyduğunu belirten intörn hemşirelerin HMYIÖ ölçeği sıra ortalamalarının diğerlerine göre anlamlı derecede düşük olduğu görüldü (KW=5,650, p=0,027). Hemşireler için alınan önlemleri yeterli bulmayanların HMYİÖ ölçeği sıra ortalamalarının diğerlerine göre anlamlı derecede düşük olduğu belirlendi ( $K W=18,217, p=0,000)$. Hemşirelik mesleğini 
isteyerek seçmeyenlerin HMYiÖ ölçeği sıra ortalamalarının mesleği isteyerek seçenlere göre anlamlı derecede düşük olduğu tespit edildi $(\mathrm{Z}=-2,501, \mathrm{p}=0,012)$, (Tablo 1).

\section{Tartışma}

COVID-19 pandemisi sürecinde intörn hemşirelerin mesleki imaj algılarının incelendiği bu çalışmada, öğrencilerin iyi düzeyde mesleki imaj algılarının olduğu belirlendi. Pandemi öncesi yapılan çalışmalar değerlendirildiğinde, Kaliforniya, Zambiya, Mısır ve Belçika'da hemşirelik öğrencilerinin imaj algılarının iyi düzeyde olduğu tespit edilmiştiri13-16. Pandemi öncesi Türkiye'de hemşirelik öğrencilerinin mesleki imaj algısında yönelik yapılan çalışmalar incelendiğinde, imaj algısının genellikle zayıf ya da orta düzeyde olduğu tespit edilmiştir6, 17-21. Hemşireler tıp ekibinin vazgeçilmez üyeleri olarak kabul edilmelerine rağmen, yapılan araştırmaların çoğunda hemşirelik statüsü düşük bir meslek olarak belirtilmiştir ${ }^{6}$. COVID-19 pandemisinin yarattığı yoğun zorluklara karşı sağlık ekibinin ön cephesinde savaşan hemşirelere toplum tarafından duyulan şükran ve sevginin öğrencilerin olumlu imaj algısına sahip olmasını desteklediği düşünülmektedir55. Türkiye'de, pandeminin başlarında halk, sağlık çalışanlarının moralini yükseltmek için 3 gün boyunca belirlenen saatte sağlık çalışanlarını evlerinin pencerelerinden alkışlayarak onlara destek olmuşlardır ${ }^{20}$. Fakat süreç ilerledikçe hiç ara vermeden çalışan, yıllık izin haklarını dahi kullanmamış olan bu fedakar grup normalleşme için atılan adımlar sonrasında tekrar artışa geçen vakalar nedeniyle kendilerini yalnız ve çaresizlik hissi içinde bulmuşlardır. Bu da onların tükenmişlik belirtileri göstermelerine neden olmuştur ${ }^{10}$. COVID-19 hastalarıyla yakın ve uzun süreli çalışmak durumunda olan sağlık çalışanları temaslı olmaları nedeniyle, toplum tarafından damgalanarak, apartman girişlerine sağlık personellerini uyaran yazılar asarak onları sosyal anlamda uzak durulması gereken kişiler olarak nitelendirmektedirler. Böylece işte yeterince yorulan, bulaş riskiyle mücadele eden hemşireler sosyal destekten de mahrum kalmaktadır ${ }^{22}$.

Türk Hemşireler Derneği hemşirelerin uygun olmayan şekilde ve yetersiz maske kullanımı, aspirasyon gibi işlemlerde yalnızca cerrahi maske kullanımının hemşireler arasında COVID-19 tanısı alma oranını arttırdığını bildirmiştir ${ }^{21}$. Çalışmada da, intörn hemşirelerin \%15’i COVID-19 geçirdiğini belirtmiştir. 
İntörn hemşireler salgın sürecinde endişe boyutlarına dair \% 67,1 oranla "kaygı duyuyorum” yanıtını vermiş olup, en çok hangi duygu ve düşüncelere sahip oldukları sorgulandığında korku, endişe hissettiklerini ifade etmişlerdir. Kaygı duyduğunu belirten intörn hemşirelerin mesleki imaj algısı düzeyi diğerlerine göre daha düşük bulunmuştur. Literatürde benzer şekilde hemşirelik öğrencileri ile yapılan çalışmalarda COVID-19 pandemisine bağlı olarak kaygı ve korku düzeylerinin yüksek olduğu belirlenmiştir7,8. Tıp öğrencileri ile hemşirelik öğrencilerinin dahil edildiği bir diğer çalışmada elde edilen sonuçlara göre ruh haliyle ilgili yapılan tümevarımsal analizler sonucunda toplanan tema duygular olumsuz olup bunlar; belirsizlik, gerginlik ve korkudur9. Yüncü ve Yılan'ın (2020) çalışmasında içerik analizi yapılarak sağlık çalışanlarının yanıtları 6 temel başlık altında toplanmıştır. Bunlar; "çalışma koşullarındaki önemli değişimler, artan iş yükü, aile hayatı üzerindeki olumsuz etkiler, artan tükenmişlik ve yönetici tutumları"dır. İlk vakayla karşılaştıklarında ne hissettikleri sorusuna yönelik olarak hemşireler en çok; korku, endişe ve tedirginlik hissettiklerini ifade etmişlerdir ${ }^{11}$.

İntörn hemşirelerin çoğunluğu hemşirelerin güvenliğine yönelik sağlı kurumlarında alınan önlemleri yeterli bulmadığını belirtmiş olup, hemşireler için alınan önlemleri yeterli bulmayan intörn hemşirelerin mesleki imaj algısı düşük düzeyde tespit edilmiştir. Pandeminin başlarında birçok ülkede güvenli bakım sağlamak için kaynakların ne kadar yetersiz olduğu haberlere yansımıştır. Kişisel koruyucu ekipmanın yetersiz oluşu, tedariki ve sınırlı test kitlerinin olduğu koşullarda işe gitmeleri kendilerini ve muhtemelen hastalarını ve ailelerini virüse yakalanma riskiyle karşı karşıya bırakmaları anlamına gelmekteydi ${ }^{23}$. OSHA (Occupational Safety and Health Administration)'nın COVID-19 enfeksiyonu riski açısından çok yüksek risk grubunda değerlendirdiği sağlık çalışanlarından olan hemşireler 24 saat durmaksızın hizmet vererek sağlık cephesinin en önünde yer almıştır ${ }^{24}$. Hemşireler kişisel koruyucu ekipman kıtlı̆̆ı, yetersiz personel, yetersiz güvenlik eğitimi ve hazırlığı dahil olmak üzere çalışma ortamı koşulları nedeniyle COVID-19 maruziyeti ve ölüm riski açısından en yüksek risk grubudurlar²5,26.

Bu çalışmada intörn hemşireler salgın döneminde aktif olarak çalışmak isterim ifadesine çoğunlukla “evet” yanıtı vermiştir. Hemşirelik öğrencilerinin COVID-19 tanısı olan hastaların tedavisine katılım istekliliğini inceleyen bir çalışmada benzer şekilde katılımcıların COVID-19 hastalarını tedavi etme isteklilik ortalama puanı 
20,19'dur27. Bu COVID-19 hastalarına tedavi ve bakım vermek için tarafsız bir istek olduğunu göstermektedir.

İntörn hemşirelerin büyük çoğunluğunun hemşirelik mesleğini isteyerek seçtiği ve mesleğini isteyerek seçmeyenlerin ise mesleki imaj algısının düşük düzeyde olduğu belirlendi. Benzer şekilde Mollaoğlu ve ark. (2010), hemşireliği tercih edenlerin teorik bilgileri daha iyi anladıkları ve mesleğe daha olumlu baktıklarını belirlemiştir ${ }^{28}$.

Mısır'da hemşirelik öğrencileriyle yapılan bir araştırmada mesleği gönüllü olarak seçen öğrencilerin imaj algılarının daha yüksek olduğu ve bulguların araştırma sonuçlarını desteklediği görülmüştür ${ }^{15}$. Meslek seçimini kendi tercihleri doğrultusunda yapmak, bireylerin motivasyonunu artırarak mutlu olmalarını sağlarken, mesleğin profesyonelliğine ve dolayısıyla mesleğin gelişimine de doğrudan etki etmektedir.

Çalışmada intörn hemşirelerin “Mesleki Nitelikler” alt boyutundan en yüksek puanı aldıkları saptanmıştır. Bu sonuç literatürde yer alan çalışma bulguları ile benzerlik göstermekte olup, Mesleki nitelikleri değerlendirildiğinde, hemşirelerin sağlıklı / hasta bireylerle en çok vakit geçiren sağlık mesleği mensupları olduğu, hemşirelerin sabırlı ve özverili, yaratıcı, yol gösterici/danışman oldukları belirtilmektedir6,29,30.

İntörn hemşirelerin "Çalışma Koşulları" alt boyutundan en düşük puan aldıkları belirlenmiştir. Literatürde de benzer şekilde pandeminin psikososyal açıdan hemşireleri olumsuz etkilediği, çalışma saatlerinin uzunluğu, kendisine, aile ve yakınlarına hastalık bulaştırma riski, bakım verilen hastaların/ekip arkadaşlarının yaşam kayıplarına tanık olma gibi faktörlerden dolayı çalışma ortamına yönelik olumsuz algıların oluştuğu belirtilmiştir31-33. COVID-19 salgını nedeniyle hemşirelerin normal çalışma saatlerinin ve iş yüklerinin yaklaşık 1,5-2 kat arttığı bildirilmiştir34. Bir diğer araştırmada hemşirelerin ailelerine bulaştırma riskinden dolayı kendilerini izole ettiklerini, aile ve yakınlarıyla görüşemediklerini eve geç gitmek zorunda kaldıklarını belirttikleri görülmektedir ${ }^{10,16}$.

COVID-19 tanılı hastalara bakım verilen kliniklerde, acil servislerde ve yoğun bakım ünitelerinde hasta sayısı artmakta olup, daha fazla hemşireye ihtiyaç duyulmaktadır. Sağlık personelinin de COVID-19 ile enfekte olması nedeniyle hemşire sayısının azalması, çalışan hemşirelerin uzun çalışma saatleri ve izinsiz/molasız çalışmaya neden olmaktadır ${ }^{4,35}$. 
COVID-19 tanılı hastalara hizmet verilen birimlerde hemşire ihtiyacını karşılamak için yeni mezun ya da farklı alanlardan hemşirelerin görevlendirilmesi yapılmaktadır. Yoğun bakım gibi detaylı bilgi ve beceri gerektiren alanlarda oryantasyon ve işbaşı eğitimleri verilmeden hemşirelerin çalışmak durumunda kalması, hem yeni görevlendirilen hem de klinikte çalışan hemşirelerin çalışma stresini arttırmaktadır²0,36. Sağlık işgücünün en büyük bileşenini oluşturan hemşirelerin, vaka sayısındaki artış, uzun çalışma saatleri, hastaların bakım taleplerinde artış, personel sayısının yetersizliği, ekipman zorlukları, hastalığa yakalanma, aileden ve sevdiklerinden soyutlanma ve bulaşma, aileye ve sevdiklerine bulaştırma stresi birleştiğinde çalışma koşulları olumsuz algılanmaktadır ${ }^{17,18,35,37 .}$

\section{Sonuç ve Öneriler}

İntörn hemşirelerin COVID-19 pandemisi sürecinde mesleki imaj algılarının iyi düzeyde olduğu ancak kaygı ve korku düzeylerinin yüksek ve çalışma koşulları alt ölçeği puanlarının düşük olduğu belirlenmiştir. Bu çalışmanın sonuçlarına göre, aşağıdakiler öneriler sunulmuştur:

- Intörnlerin ve hemşirelerin güvenle çalışabilecekleri ortamların desteklenmesi,

- Salgınla mücadele konusunda kendilerini yalnız hissetmelerinin önüne geçecek maddi ve manevi motivasyon desteğinin sağlanması,

- Ücret ve çalışma düzenlerinin iyileştirilmesi,

- Sağlıkta şiddete yönelik caydırıcı yasal zeminin oluşturulması gereklidir.

\section{KAYNAKLAR}

1. Kiyat İ, Karaman S, İşcan Ataşen G, Elkan Kiyat Z. Yeni koronavirüs (COVID-19) ile mücadelede Hemşirelik. Türk Hemşireler Derneği Dergisi. 2020;1(1):81-90.

2. Sağlık Bakanlığı. Covid-19 Sözlüğü 2020. TC Sağlık Bakanlığı.

https://covid19.saglik.gov.tr/TR-

66494/pandemi.html\#: :text=Bir\%2ohastal\%C4\%B1\%C4\%9F\%C4\%B1n\%2oveya \%20enfeksiyon\%2oetkeninin,DS\%C3\%96)\%2otaraf\%C4\%B1ndan\%2opandemi\%2 oilan\%20edilmi\%C5\%9Ftir. Erişim Tarihi 2 Kasım 2020. 
3. Sağlık Bakanlığı. Türkiye Covid-19 Hasta Tablosu 2020. TC Sağlık Bakanlığı. https://covid19.saglik.gov.tr/. Erişim tarihi 6 Mart 2021.

4. Çevirme A, Kurt A. COVID-19 pandemisi ve hemşirelik mesleğine yansımaları. Avrasya Sosyal ve Ekonomi Araştırmaları Dergisi. 2020; 2:46-52.

5. Bennett CL, James AH, Kelly D. Beyond tropes: Towards a new image of nursing in the wake of COVID-19. J Clin Nurs. 2020;29(15-16):2753-2755. doi: 10.1111/jocn.15346.

6. Kızılcık Özkan Z, Ünver S, Avcıbaşı İ, Semerci R, Yıldız Fındık Ü. Bir grup hemşirelik öğrencisinin mesleğe yönelik imaj algısı. Hemşirelikte Araşturma Geliştirme Dergisi. 2017;19(1):38-47.

7. Akman Ö, Yıldırım D, Sarıkaya A. Covid-19 pandemisinin hemşirelik öğrencilerinin kaygı düzeylerine etkisi. İstanbul Gelişim Üniversitesi Sağlık Bilimleri Dergisi. 2020;12:379-397. doi:10.38079/igusabder.757110.

8. Lovrić R, Farčić N, Mikšić Š, Vcev A. Studying during the COVID-19 pandemic: a qualitative inductive content analysis of nursing students' perceptions and experiences. Education Sciences. 2020;10:188. doi:10.3390/educsci10070188.

9. Collado-Boira EJ, Ruiz-Palomino E, Salas-Media P, Folch-Ayora A, Muriach M, Baliño P. The covid-19 outbreak -an empirical phenomenological study on perceptions and psychosocial considerations surrounding the immediate incorporation of final-year Spanish nursing and medical students into the health system. Nurse Education Today. 2020;92:104504. doi:10.1016/j.nedt.2020.104504.

10. Güvenç R, Baltacı E. Covid-19 ve sağlık çalışanlarının ruh sağlığı. Türk Tabipler Birliği Covid-19 Altıncı Ay Değerlendirme Raporu. 2021.

11. Yüncü V, Yılan Y. Covid-19 pandemisinin sağlık çalışanlarına etkilerinin incelenmesi: bir durum analizi. Iğdır Üniversitesi Sosyal Bilimler Dergisi. 2020;373-401.

12. Dost A, Bahcecik AN. Developing a scale for the image of nursing profession. Journal of Academic Research in Nursing. 2015;1(2):51-59. doi: 10.5222/jaren.2015.051.

13. Zulu C, Ngoma C. A survey on perception of the image of the nursing profession in Zambia by nursing students at the department of nursing sciences, University of Zambia. Unified Journal of Nursing and Midwifery. 2015;1(1):1-14. 
14. Siebens K, Casterle BD, Abraham I, et al. The professional self-image of nurses in Belgian hospitals: a crosssectional questionnaire survey. International Journal of Nursing Studies. 2006;43:71-82. doi:10.1016/j.ijnurstu.2005.04.004.

15. Mohamed AMG. Implications of stereotypical self and public nursing image on performance of nurses and nursing students. IAEME Publication. 2013;4(3):151162.

16. Seago JA, Spetz AA, Keane D, Grumbach K. The nursing shortage: is it really about image? Journal of Healthcare Management. 2006;51:96-110.

17. Tan M, Şentürk Ö, Yuncu S, Yıldız Ö. Üniversite öğrencilerinin hemşireliğe bakış açlları. Atatürk Üniversitesi Hemşirelik Yüksekokulu Dergisi. 2007;(10):1-29.

18. Deniz Akan D, Koşar Şahin C, Sevgi Doğan E, Yıldız S, Göktaş G, Çınar Pakyüz S. Hemşirelik öğrencilerinin hemşirelik imajına yönelik algıları ile akademik motivasyonları arasındaki ilişkinin incelenmesi. İnönü Üniversitesi Sağlık Hizmetleri Meslek Yüksek Okulu Dergisi. 2021;9(1):362-373. doi:10.33715/inonusaglik.794807.

19. Karaman F, Çakmak S, Yerabakan AN. Hemşirelik öğrencilerinin mesleğe yönelik imaj algıları ve etkileyen faktörlerin belirlenmesi. İstanbul Gelişim Üniversitesi Sağlık Bilimleri Dergisi. 2020;(11):217-229.

20. Kackin O, Ciydem E, Aci OS, Kutlu FY. Experiences and psychosocial problems of nurses caring for patients diagnosed with Covid-19 in Turkey: a qualitative study. The International Journal of Social Psychiatry. 2020;(00):1-10. doi:10.1177/0020764020942788

21. Türk Hemşireler Derneği. Covid- 19 mevcut durum analizi raporu, 2020. Türk Hemşireler Derneği. https://www.thder.org.tr/uploads/files/EK-SBHemsirelerin-Durum-Analizi 5.Rapor.pdf. Erişim tarihi 27 Mayıs 2020. 22. Acil Durumlarda Ruh Sağlığı ve Psikososyal Destek Referans Grubu. Covid-19 salgınının ruh sağlı̆̆ı ve psikososyal etkenler açısından ele alınması, versiyon 1.5. MEDBOX. https://www.medbox.org/pdf/5e8741c223c1bo1b330a3212. Erişim tarihi 17 Mart 2020.

23. McKenna H. Covid-19: ethical issues for nurses. Int J Nurs Stud. 2020;110:103673. doi: 10.1016/j.ijnurstu.2020.103673. 
24. Occupational Safety and Health Administration. Control and prevention. United States Department of Labor. https://www.osha.gov/SLTC/covid-19/. Erişim tarihi 27 Mayıs 2020.

25. Jackson D, Anders R, Padula WV, Daly J, Davidson PM. Vulnerability of nurse and physicians with Covid-19: monitoring and surveillance needed. J. Clin. Nurs. 2020;8(29):3584-3587.

26. Gómez-Ochoa SA, Franco OH, Rojas LZ, et al. Covid-19 in healthcare workers: a systematic review and meta-analysis of prevalence, risk factors, clinical characteristics, and outcomes. Am. J. Epidemiol. 2021;190(1):161-175.

27. Alshutwi SS. 'Senior nursing students and interns' concerns and willingness to treat patients with Covid-19: a strategy to expand national nursing workforce during the covid-19 pandemic. Risk Management and Healthcare Policy. 2021;(14):39-48._doi:10.2147/RMHP.S279569.

28. Mollaoğlu M, Fertelli T, Tuncay F. Hastanede çalışan hemşirelerin çalışma ortamlarına ilişkin algılarının değerlendirilmesi. Frat Sağlık Hizmetleri Dergisi. 2010;5(15):17-30.

29. Özmen D, Çetinkaya A. Hemşirelik son sınıf öğrencilerinin mesleki algılarına yönelik nitel bir çalışma. Hemşirelikte Araştırma Geliştirme Dergisi. 2016;18(1):40-52.

30. Yilmaz D. Professional image perceptions in first-year nursing students. Journal of Client-Centered Nursing Care. 2019;5(3):141-146.

31. Maben J, Bridges J. Covid-19: supporting nurses' psychological and mental health. J Clin Nurs. 2020;(15-16):2742-2750. doi:10.1111/jocn.15307.

32. Ghasempour M, Purabdollah M. Necessity of attention to mental health of the front line nurses against covid-19: a forgotten requirement. International Journal of Community Based Nursing \& Midwifery. 2020;8(3):280-281.

33. Cheung T, Fong TK, Bressington D. Covid-19 under the SARS cloud: mental health nursing during the pandemic in Hong Kong. J Psychiatr Ment Health Nurs. 2020;28(2):115-117. doi:10.1111/jpm.12639.

34. Sun N, Shi S, Jiao D, et al. A qualitative study on the psychological experience of caregivers of COVID-19 patients. American Journal of Infection Control. 2020;(48):592-598. doi:10.1016/j.ajic.2020.03.018. 
35. Levin J. Mental health care for survivors and healthcare workers in the aftermath of an outbreak. Psychiatry of Pandemics. 2019:127-141. doi: 10.1007/978-3-03015346-5_11.

36. National Center for Posttraumatic Stress Disorders. Managing healthcare workers' stress associated with the covid-19 virus outbreak. US Department of Veterans Affairs. https://www.ptsd.va.gov/covid/COVID healthcare workers.asp. Erişim tarihi 6 Mart 2021.

37. Shen X, Zou X, Zhong X, Yan J, Li L. Psychological stress of ICU nurses in the time of Covid-19. Critical Care. 2020;6(24):200. doi:10.1186/s13054-020-02926-2. 